\title{
Technical and Technological Factors' Effects on Quality of the Machined Surface and Energetic Efficiency When Planar Milling Heat-treated Meranti Wood
}

\author{
L’ubomír Rajko, Peter Koleda, * Štefan Barcík, and Pavol Koleda \\ As heat-treated wood has an ever-increasing application, the research of \\ its machining is the subject of many studies. This article investigated the \\ technical, technological, material, and tool-related factors that influence \\ the quality of the machined surface (average roughness $R_{\mathrm{a}}$ ) and energy \\ consumption during the process of planar milling of heat-treated meranti \\ wood. The experimental measurements were performed on samples that \\ were treated by four methods at temperatures of $160^{\circ} \mathrm{C}, 180^{\circ} \mathrm{C}, 200^{\circ} \mathrm{C}$, \\ and $220^{\circ} \mathrm{C}$. One sample was in its natural state. The cutting conditions \\ were as follows: feed rates $6 \mathrm{~m} \times \mathrm{min}^{-1}, 10 \mathrm{~m} \times \mathrm{min}^{-1}$, and $15 \mathrm{~m} \times \mathrm{min}^{-1}$,

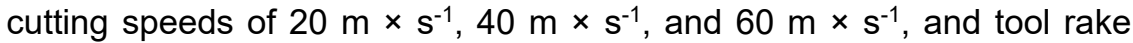 \\ angles of $20^{\circ}, 25^{\circ}$, and $30^{\circ}$. Experimental measurement of the surface \\ roughness was performed using an LPM - 4 profilometer. Individual \\ measurements of cutting power were performed via a frequency converter. \\ The experiments determined the effects of the individual parameters on \\ surface roughness in the following order: rake angle, heat treatment of the \\ material, feed rate, and cutting speed. The effects of observed parameters \\ on energetic efficiency were in the order: cutting speed, feed rate, rake \\ angle, and heat treatment.
}

Keywords: Plane milling; Meranti; Surface roughness; ThermoWood; Quality of machining; Cutting power

Contact information: Department of Manufacturing and Automation Technology, Faculty of Technology, Technical University in Zvolen, Študentská ulica 26, Zvolen, 960 01, Slovakia;

*Corresponding author: peter.koleda@tuzvo.sk

\section{INTRODUCTION}

Recently, to increase the potential of wood as a production material, thermal modification has been used. This approach is based on the action of high temperatures (from $150{ }^{\circ} \mathrm{C}$ to $260{ }^{\circ} \mathrm{C}$ ) causing thermal and hydrothermal changes in the structure of wood (Reinprecht and Vidholdová 2008). Because of the high temperatures, polymers degrade, and new substances are formed, which are insoluble in water and have a toxic or repellent effect on biological pests, such as fungi. Thermal modification reduces the hygroscopicity of wood, improves its shape stability, and changes its colour (Hill 2006; Boonstra et al. 2007; Esteves and Pereira 2009; Kučerová et al. 2016; Sikora et al. 2018; Kúdela et al. 2020). The process of thermal modification is carried out by two standard treatments, which include Thermo-S and Thermo-D. Thermo-S is a process that is carried out at lower temperatures (approx. $185{ }^{\circ} \mathrm{C}$ ), and it is mainly used in the interior. The Thermo-D process is carried out at higher temperatures (approx. $200^{\circ} \mathrm{C}$ ), which increases the durability of the treated material (Kaplan et al. 2018).

The growing consumption of thermally modified wood is also related to its processing, which affects surface quality after machining. Wood modified by heat is 
subjected to the same technological processing as natural wood (Černecký et al. 2017). The most common method of mechanical woodworking is chip cutting, which includes milling (Siklienka and Kminiak 2013). Heat-treated wood can be used for composite processing (Kminiak et al. 2020). The presence of small particles that have a negative impact on living and working environments was not observed in the process of machining heat-treated wood at a CNC (Computerized Numerical Control) machining centre (Kminiak and Dzurenda 2019). However, particles dangerous to humans were observed in wood milling of wood treated at temperatures over $200^{\circ} \mathrm{C}$ (Očkajová et al. 2020a, 2020b). Surface quality during machining is directly proportional to the physical and mechanical properties of wood and the technical and technological conditions of the milling process (Prokeš 1982; Barcík et al. 2014). Surface quality during woodworking can be greatly influenced by the cutting conditions of the milling process (Lisičan 1996). During milling, the energy consumption is influenced by various factors, such as the material of the cutting tool, the geometry of the tool, the cutting conditions, and the cutting power. When machining a material, the energy consumption is typically determined by observing the cutting power (Koleda et al. 2018; Koleda et al. 2021).

This study examined the influence of individual selected milling factors of thermally modified meranti wood (Shorea acuminata) on surface treatment quality and energy intensity. This study aimed to illustrate the individual differences between natural and thermally modified wood in terms of the machined surface quality and the consumed cutting power in the process of face milling.

\section{EXPERIMENTAL}

\section{Materials and Methods}

Surface-induction-hardened knives from tool steel Maximum Special 55: 1985/5 with a hardness of $64 \mathrm{HRC}$ were used for experimental milling (Fig. 1). The milling knives were further coated by PVD (physical vapor deposition). The coating process was carried out by WOOD-B S. R. O. in Nové Zámky, Slovakia. The chemical composition of the knives is shown in Table 1.
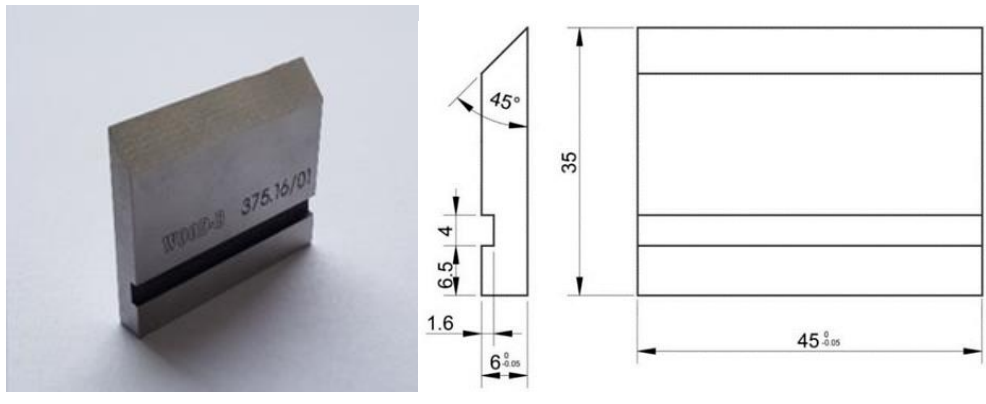

Fig. 1. Changeable milling knife

Table 1. Chemical Composition of Used Milling Knives

\begin{tabular}{|c|c|c|c|c|c|c|c|}
\hline \multicolumn{7}{|c|}{ Tool Steel 19573} \\
\hline Co & Mn & Si & P & S & Cr & Mo & V \\
\hline $1.4 \div 1.65$ & $0.2 \div 0.45$ & $0.2 \div 0.45$ & 0.03 & 0.035 & $11 \div 12.5$ & $0.6 \div 0.95$ & $0.8 \div 1.20$ \\
\hline
\end{tabular}


The knives were clamped in FH 45 STATON milling heads manufactured by SZT Machines (Turany, Slovakia) (Fig. 2), and their parameters are listed in Table 2.

Table 2. Parameters of the Milling Heads

\begin{tabular}{|c|c|}
\hline Head Diameter $(\mathrm{mm})$ & 125 \\
\hline Head Diameter with Mounted Knife $(\mathrm{mm})$ & 130 \\
\hline Milling Head Width $(\mathrm{mm})$ & 45 \\
\hline Number of Knives $(-)$ & 2 \\
\hline Maximal Revolutions (rpm) & 8000 \\
\hline Rake Angle $\left(^{\circ}\right)$ & $20^{\circ}, 25^{\circ}, 30^{\circ}$ \\
\hline
\end{tabular}

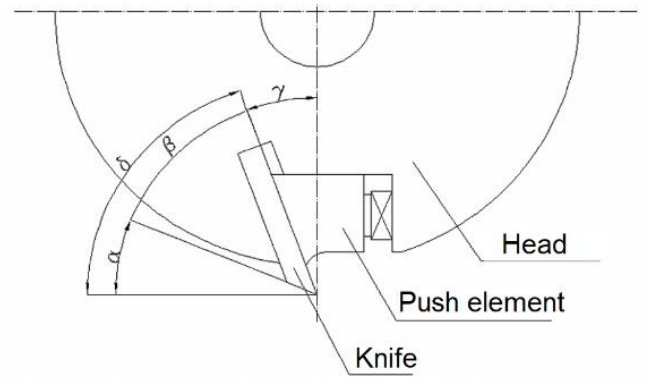

Fig. 2. Schematic of the milling head used in this experiment

The samples of meranti wood (Shorea acuminata) from Malaysia were used in the experiment (Fig. 3), the region of origin was not specified by the importer (Wood Store, Prague, Czech Republic).

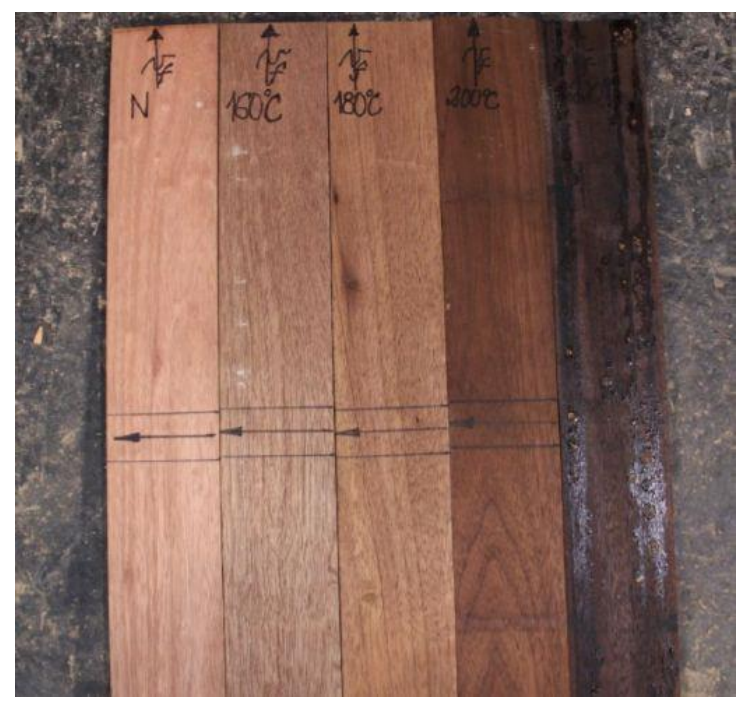

Fig. 3. The prepared wood samples

Boards of radial central lumber with a thickness of $25 \mathrm{~mm}$ were cut with an MTZ $1000 \log$ band saw (MEBOR d.o.o., Železniki, Slovenia). The boards were dried to 10\% humidity in a lumber kiln at the Technical University in Zvolen (Zvolen, Slovakia). Samples were obtained using a DMMA 35 circular saw (Rema, s.a., Reszel, Poland) and a F2T80 planer (TOS Svitavy, Czech Republic). The final dimensions of the samples were $(1 \times \mathrm{w} \times \mathrm{d}) 700 \mathrm{~mm} \times 100 \mathrm{~mm} \times 25 \mathrm{~mm}$. One set of samples was not heat treated and was 
examined as a natural material. Thermal modification of the other samples was performed using ThermoWood technology with the method described by Hrčková et al. (2018). Figure 4 shows the course of the heat treatment of the samples. They were treated in a LAC S400/03 type chamber (Katres, Ríčany, Czech Republic).

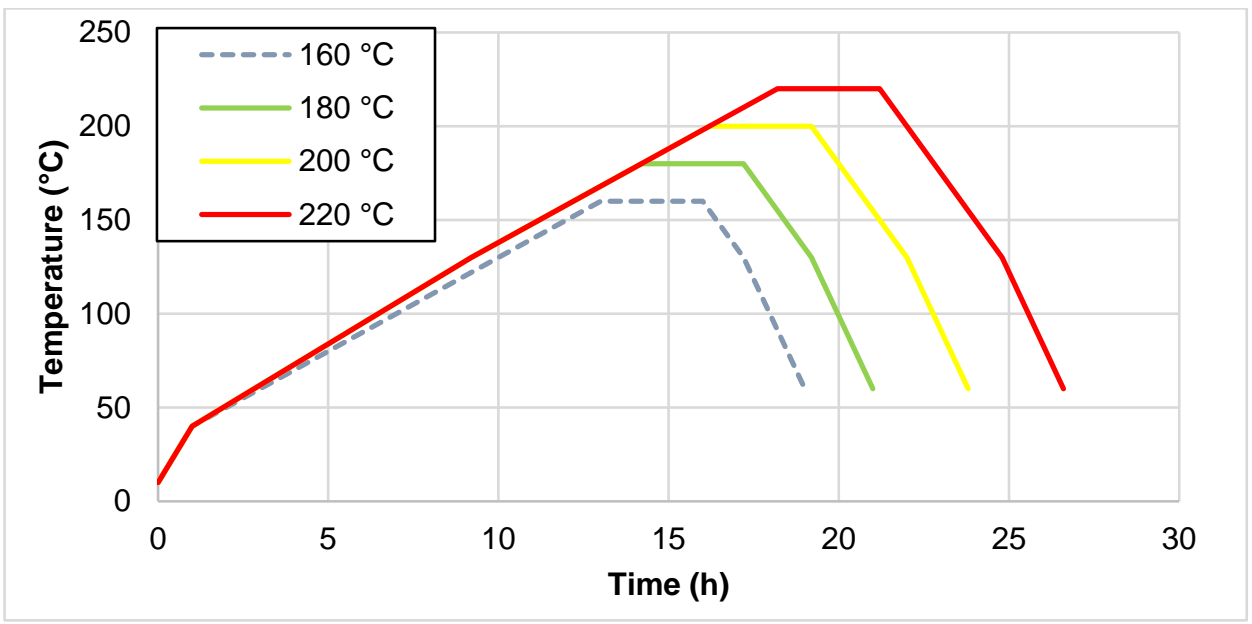

Fig. 4. The course of heat treatment over time

Milling of samples was performed on an experimental device, which consisted of an FVS lower spindle milling machine (Czechoslovakia Musical Instruments, Hradec Králové, Czech Republic) and a Frommia ZMD 252/137 feeding mechanism (Maschinenfabrik Ferdinand Fromm, Fellbach, Nemecko) (Fig. 5). The cutting conditions during milling were cutting speeds of $20 \mathrm{~m} \times \mathrm{s}^{-1}, 40 \mathrm{~m} \times \mathrm{s}^{-1}$, and $60 \mathrm{~m} \times \mathrm{s}^{-1}$, feed rates of $6 \mathrm{~m} \times \mathrm{min}^{-1}, 10 \mathrm{~m} \times \mathrm{min}^{-1}$, and $15 \mathrm{~m} \times \mathrm{min}^{-1}$, and rake angles of $20^{\circ}, 25^{\circ}$, and $30^{\circ}$.

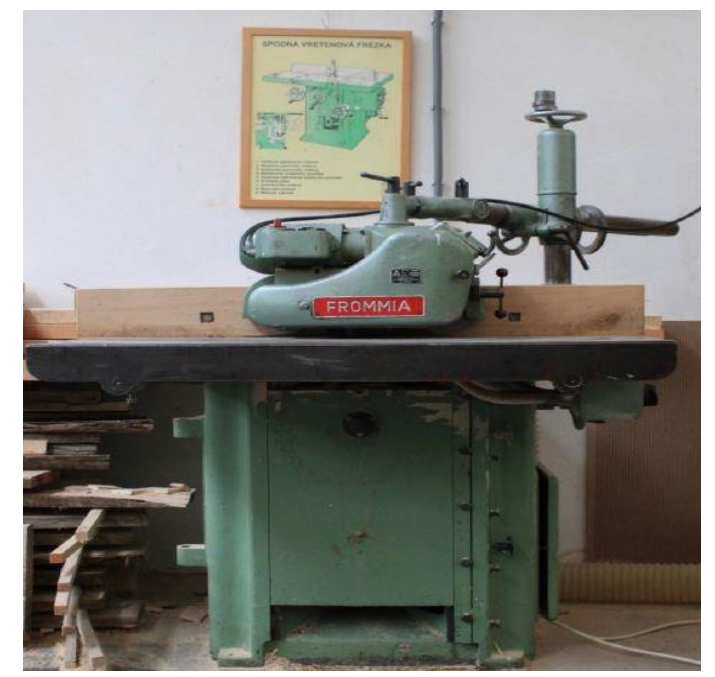

Fig. 5. The FVS lower spindle milling machine and the Frommia ZMD 252/137 feeding mechanism 
Table 3. Technical Parameters of Milling Machine and Feeding Mechanism

\begin{tabular}{|c|c||c|c|}
\hline \multicolumn{2}{|c||}{ FVS Milling Machine } & \multicolumn{2}{c|}{ Frommia ZMD 252/137 Feeder } \\
\hline Input Power $(\mathrm{kW})$ & 4 & Feed Range $\left(\mathrm{m} \times \mathrm{min}^{-1}\right)$ & $2.5 ; 10 ; 15 ; 20 ; 30$ \\
\hline Voltage $(\mathrm{V})$ & $360 / 220$ & Motor $\left(\mathrm{m} \times \mathrm{min}^{-1}\right)$ & $380 ; 2800$ \\
\hline Year of Manufacture & 1976 & Year of Manufacture & 1972 \\
\hline
\end{tabular}

Measurements of the individual samples were performed according to STN 490108 (1993) (Wood. Determination of density). The weight of the samples was measured via a laboratory scale with a measurement accuracy of $0.01 \mathrm{~g}$. The dimensions were measured by a calliper with an accuracy of $0.01 \mathrm{~mm}$. The resulting values of the sample dimensions and weights were recorded as the mean of 10 measurements. The wood density, which was calculated as the ratio of weight to volume, decreased with as treatment temperature increased.

Table 4. Calculated Values of Samples Density

\begin{tabular}{|c|c|c|}
\hline Temperature $\left({ }^{\circ} \mathrm{C}\right)$ & Density $\left(\mathrm{kg}^{\circ} \times \mathrm{m}^{-3}\right)$ & Change Relative to Native $(\%)$ \\
\hline Native & 639 & - \\
\hline 160 & 617 & 3.44 \\
\hline 180 & 580 & 9.23 \\
\hline 200 & 559 & 12.52 \\
\hline 220 & 549 & 14.08 \\
\hline
\end{tabular}

The noncontact roughness measurements were performed using a LPM-4 laser profilometer (KVANT Ltd., Bratislava, Slovakia), and the results were compiled at the Department of Woodworking of the Technical University in Zvolen, Slovakia (Fig. 6). Surface roughness measurements were performed on a $40-\mathrm{mm}$-long section in the middle of the samples, in four lines from the edge. The distances of the individual lines were 4 $\mathrm{mm}, 8 \mathrm{~mm} 12 \mathrm{~mm}$, and $16 \mathrm{~mm}$ from the reference edge. The overall surface assessment was performed in accordance with ISO 4287 (1997) (Geometrical Product Specifications (GPS) - Surface texture: Profile method - Terms, definitions, and surface texture parameters). The technical parameters of the device, measurement technique, and data processing were described by Korčok et al. (2018a, 2018b). 


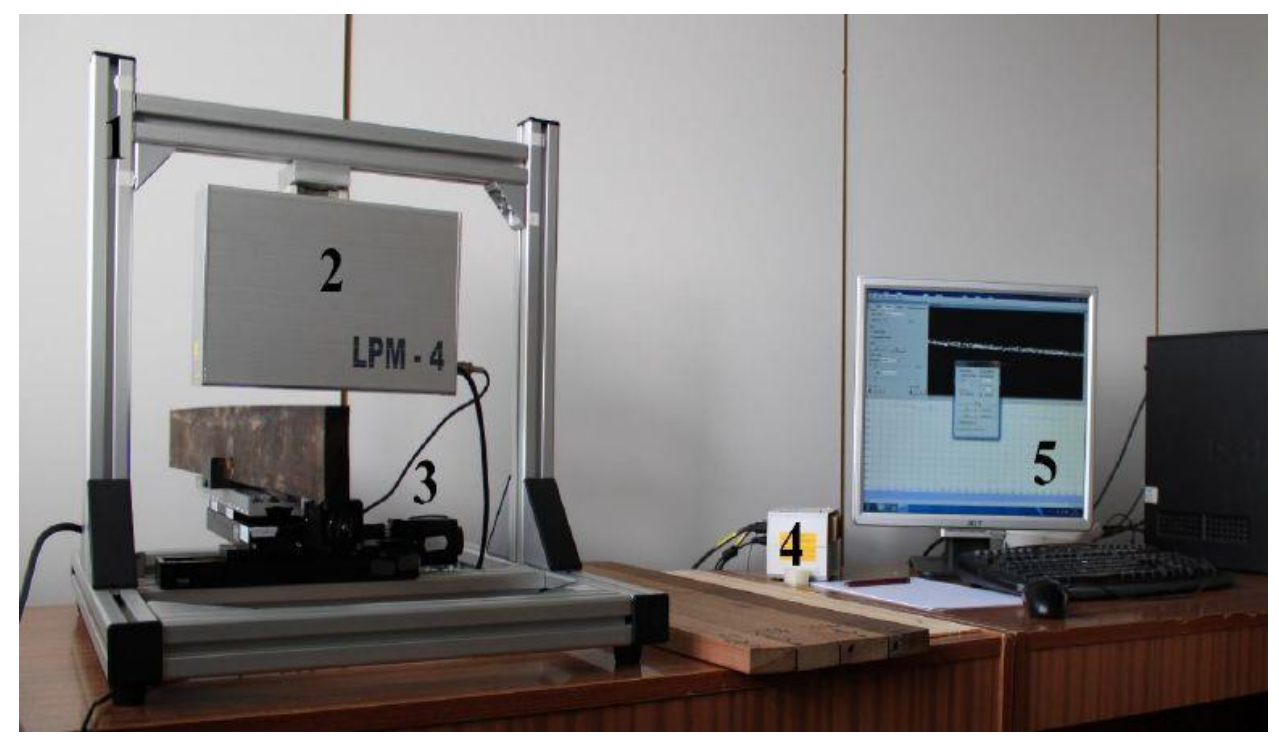

Fig. 6. The LPM-4 laser profilometer: (1) framework; (2) profilometric head; (3) feed for $X$ and $Z$ axes; (4) control unit; (5) computer with software

The UNIFREM 400 007M frequency converter (5.5 kW for constant load) (Vonsch, Slovakia) was used to measure power consumption during milling, and it was connected to a computer via a USB (Universal Serial Bus) serial interface. From the current, voltage, and power factor of the motor, the power and power input of the motor were determined without loss and recorded via Vonsch Drive Studio 2.2 (VONSCH S. R. O., Brezno, Slovakia). The output voltage of the converter was smoothed by a SKY3FSM25 sine filter (VONSCH S. R. O., Brezno, Slovakia) (Fig. 7).

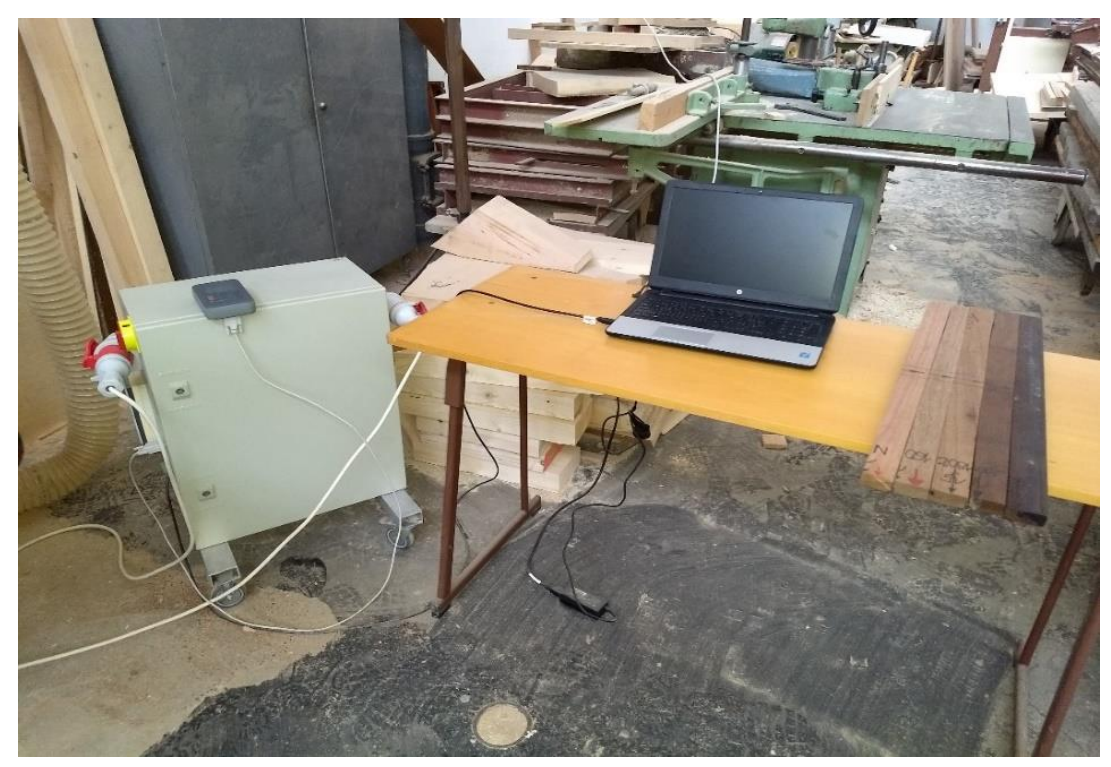

Fig. 7. The system for cutting power measurement

The measured surface roughness and cutting power values were processed in Excel 2016 (Microsoft Corporation, version 18.2008.12711.0, Redmond, WA, USA) and STATISTICA 12 (StatSoft, Tulsa, OK, USA), which was used to evaluate their statistical significance by ANOVA (analysis of variance) and F-test. 


\section{RESULTS AND DISCUSSION}

\section{Influence of Thermal Treatment on the Surface Roughness}

The roughness was affected by the heat treatment mode (Fig. 8). The highest value of surface roughness was observed for heat treatment at $220{ }^{\circ} \mathrm{C}$. The opposite effect was seen with heat treatment at $160{ }^{\circ} \mathrm{C}$, which resulted in the best surface roughness. Thus, it was clear that the surface roughness after milling increased as the thermal modification of the material increased. At temperatures of 160 and $180{ }^{\circ} \mathrm{C}$, thermal degradation and chemical changes of lignin compensated microgeometric inequalities of wood, which can be observed even after its milling in lower roughness. At higher temperatures, lignin is degraded to such an extent that it evaporates, the wood becomes more brittle, its microirregularities increased.

\section{Influence of Feed rate on the Surface Roughness}

The multifactor analysis of the variance of the surface roughness versus feed rate is shown in Fig. 9. There was a slight deviation in native wood, as the worst surface quality was observed at the lowest feed rate of $6 \mathrm{~m} \times \mathrm{min}^{-1}$. Further, the highest surface roughness was achieved with heat-treated wood at $220^{\circ} \mathrm{C}$ with a feed rate of $15 \mathrm{~m} \times \mathrm{min}^{-1}$. The quality of the wood surface was the best with wood heat treatment at $160{ }^{\circ} \mathrm{C}$ with a feed rate of 6 $\mathrm{m} \times \min ^{-1}$.

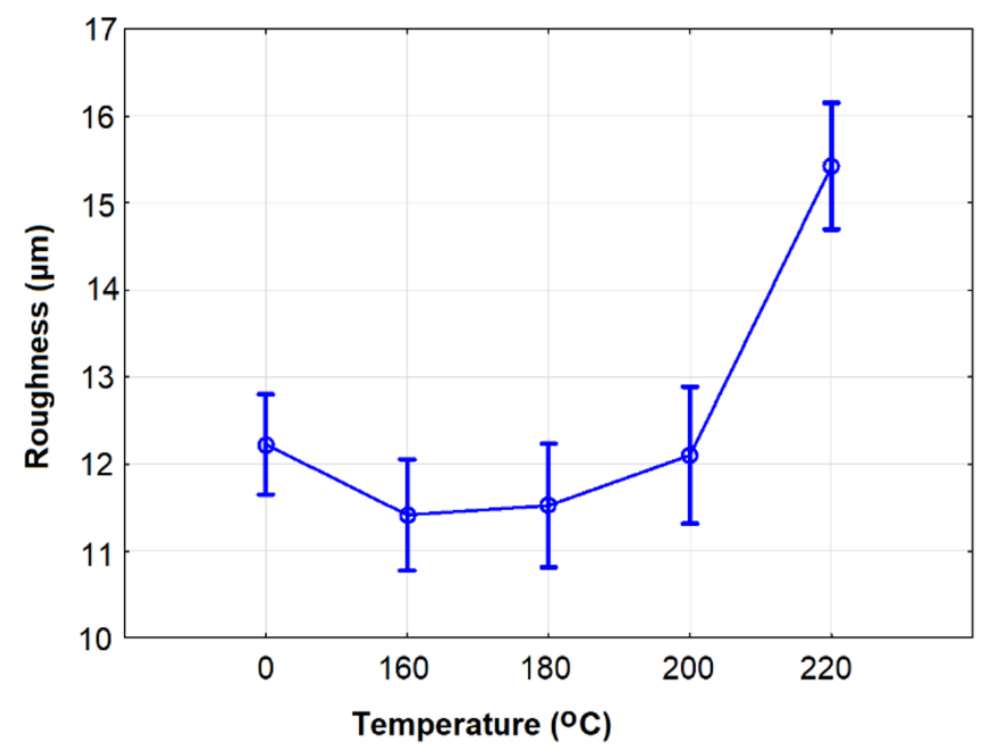

Fig. 8. Effect of thermal treatment on the material surface roughness 


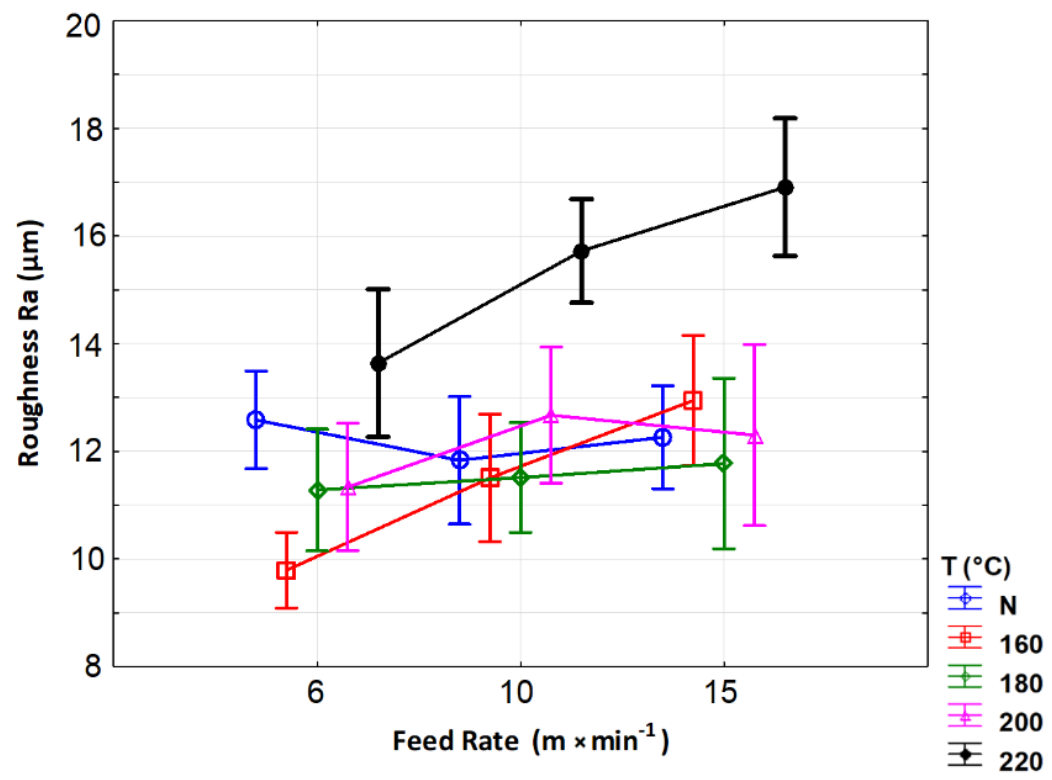

Fig. 9. Multifactor analysis of variance for the dependence of surface roughness on feed rate

\section{Influence of Rake Angle on the Surface Roughness}

The angular geometry of the tool was directly involved in the material machining process and affected the quality of the machined surface. A multifactor analysis of the variance of the surface roughness versus rake angle is shown in Fig. 10. The best surface roughness values were obtained with heat treatment at $180^{\circ} \mathrm{C}$. The best surface quality was achieved at a rake angle of $30^{\circ}$. In contrast, the worst surface quality was recorded with a sample heat treated at $220^{\circ} \mathrm{C}$ and a rake angle of $20^{\circ}$.

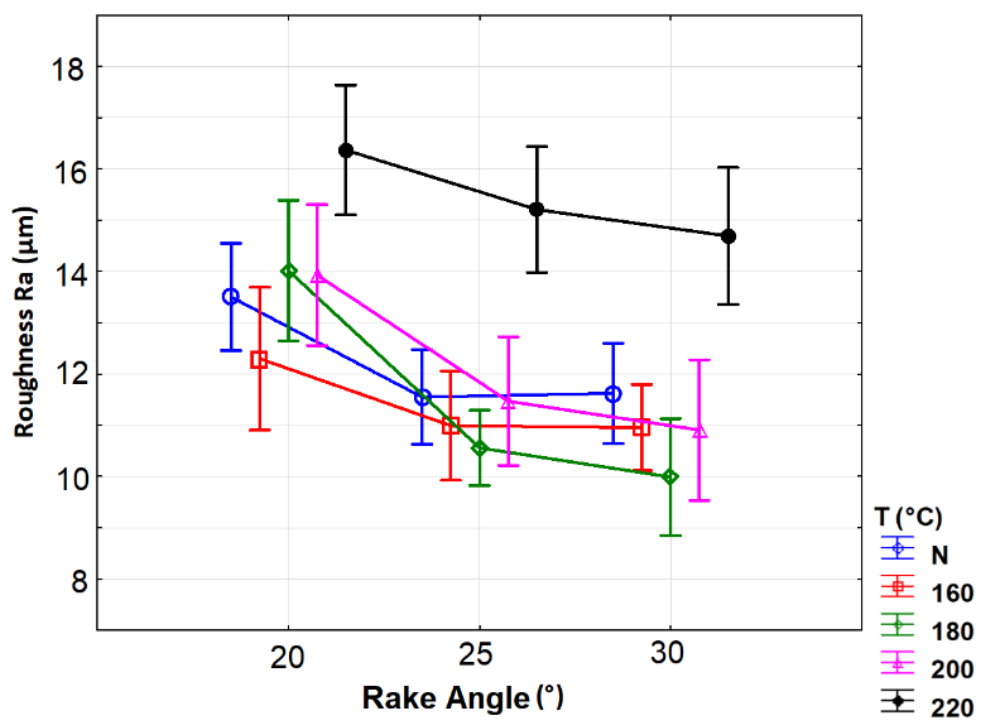

Fig. 10. Multifactor analysis of variance for the dependence of surface roughness on rake angle

\section{Influence of Cutting Speed on the Surface Roughness}

Cutting speed was another factor that affected surface roughness during the milling process, but no statistically significant effect was demonstrated $(\mathrm{p}>0.05)$ (Table 5). A 
multifactor analysis of the variance of surface roughness versus cutting speed is shown in Fig. 11. According to the theory of machining, increasing the cutting speed reduces the micro geometric roughness. The opposite trend was observed for the sample heat treated at $160{ }^{\circ} \mathrm{C}$ and for native wood, as their surface roughness increased as cutting speed increased. The worst surface quality was observed in the sample that was heat treated at $220^{\circ} \mathrm{C}$ with a cutting speed of $20 \mathrm{~m}^{\circ} \mathrm{s}^{-1}$. The best surface roughness was achieved with a sample heat treated at $160{ }^{\circ} \mathrm{C}$ and a cutting speed of $20 \mathrm{~m} \times \mathrm{s}^{-1}$.

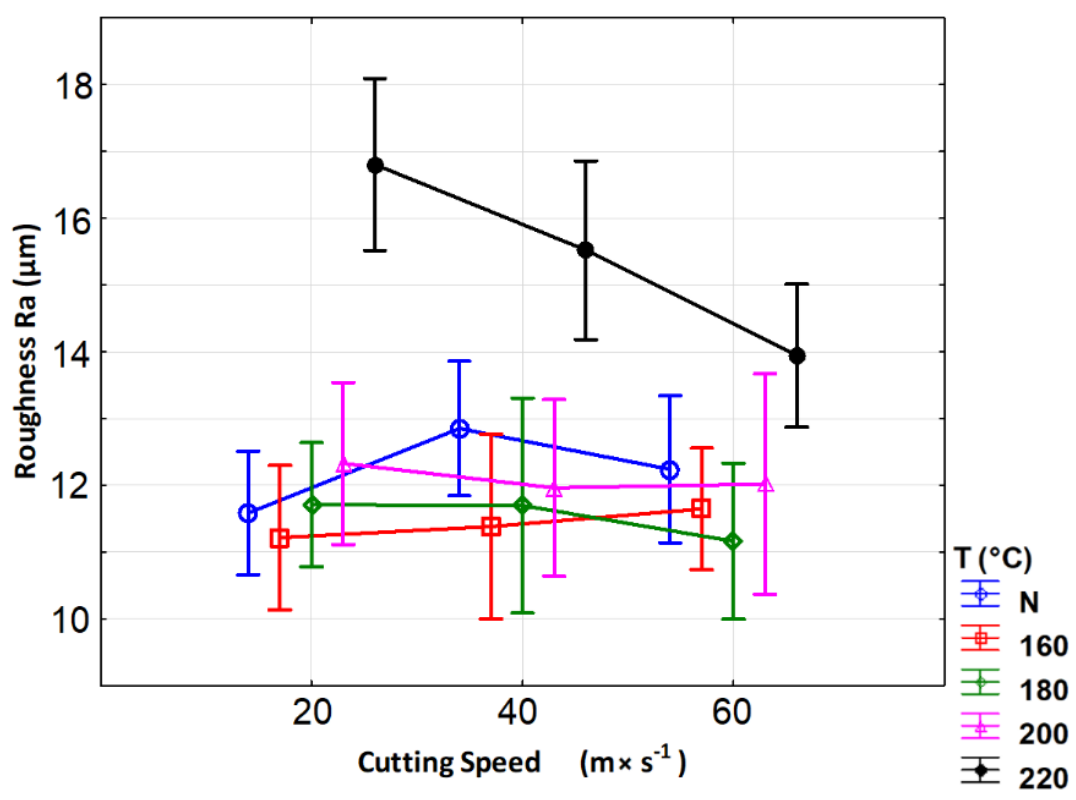

Fig. 11. Multifactor analysis of variance for the dependence of surface roughness on cutting speed

Table 5. The Order of the Effects of Various Factors on Surface Roughness

\begin{tabular}{|c|c|c|}
\hline Effect on Surface Roughness & F-test & $\begin{array}{c}\text { Significance level } \\
(\mathrm{p})\end{array}$ \\
\hline Rake Angle $\left({ }^{\circ}\right)$ & 57.13 & 0.000 \\
\hline Temperature of Heat Treatment $\left({ }^{\circ} \mathrm{C}\right)$ & 55.53 & 0.000 \\
\hline Feed Rate $\left(\mathrm{m} \times \mathrm{min}^{-1}\right)$ & 19.71 & 0.000 \\
\hline Cutting Speed $\left({\left.\mathrm{m} \times \mathrm{s}^{-1}\right)}\right.$ & 2.88 & 0.057 \\
\hline
\end{tabular}

\section{Influence of Thermal Treatment on the Cutting Power}

Figure 12 shows that the milling process had the highest cutting power for natural wood. The subsequent decrease in cutting power occurred for the samples thermally treated at 160 and $180{ }^{\circ} \mathrm{C}$. For the samples heat treated at 200 and $220{ }^{\circ} \mathrm{C}$, the cutting power increased. This can be caused by the inhomogeneous structure of the wood, resp. by not heat-treating the sample throughout the cross-section. The lowest achieved value of cutting power was observed with the sample heat treated at $180{ }^{\circ} \mathrm{C}$. 


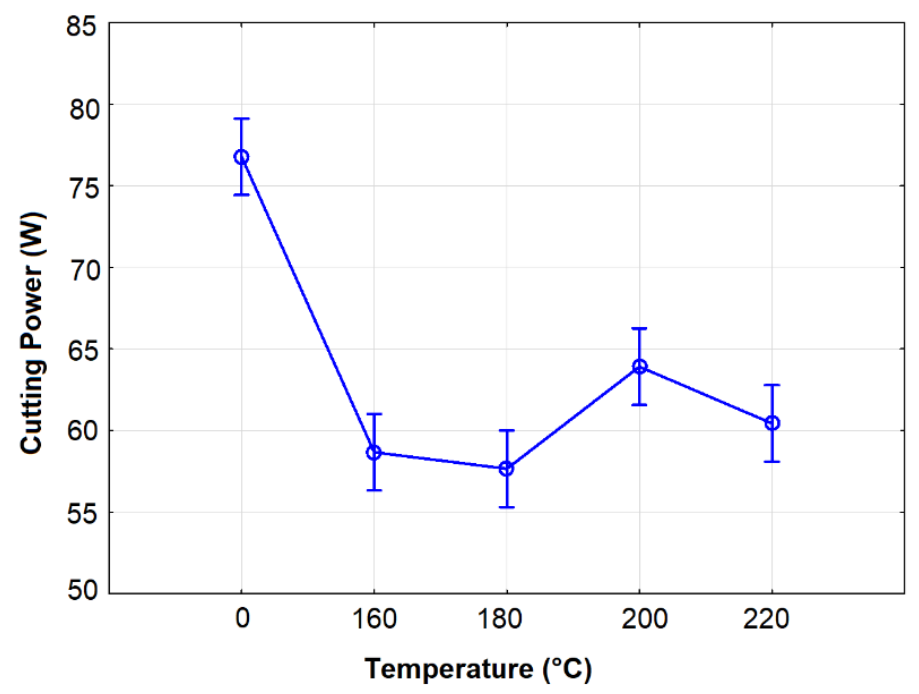

Fig. 12. Effect of thermal treatment on cutting power

\section{Influence of Feed rate on Cutting Power}

The multifactor analysis of variance of the dependence of feed rate on cutting power is shown in Fig. 13. The highest achieved cutting power was observed with native wood and a feed speed of $15 \mathrm{~m} \times \mathrm{min}^{-1}$. In contrast, the lowest cutting power was achieved with the sample heat treated at $160{ }^{\circ} \mathrm{C}$ with a feed rate of $10 \mathrm{~m} \times \mathrm{min}^{-1}$. Modification of the samples at $200{ }^{\circ} \mathrm{C}$ and $220{ }^{\circ} \mathrm{C}$ showed that the cutting power values were approximately equal for feed rates of $6 \mathrm{~m} \times \mathrm{min}^{-1}$ and $10 \mathrm{~m} \times \mathrm{min}^{-1}$. Further, approximately equal cutting power values were observed for samples thermally treated at 160 and $180{ }^{\circ} \mathrm{C}$ with a feed speed of $6 \mathrm{~m} \times \mathrm{min}^{-1}$ and for samples thermally treated at 180 and $220^{\circ} \mathrm{C}$ with a feed speed of $15 \mathrm{~m} \times \mathrm{min}^{-1}$.

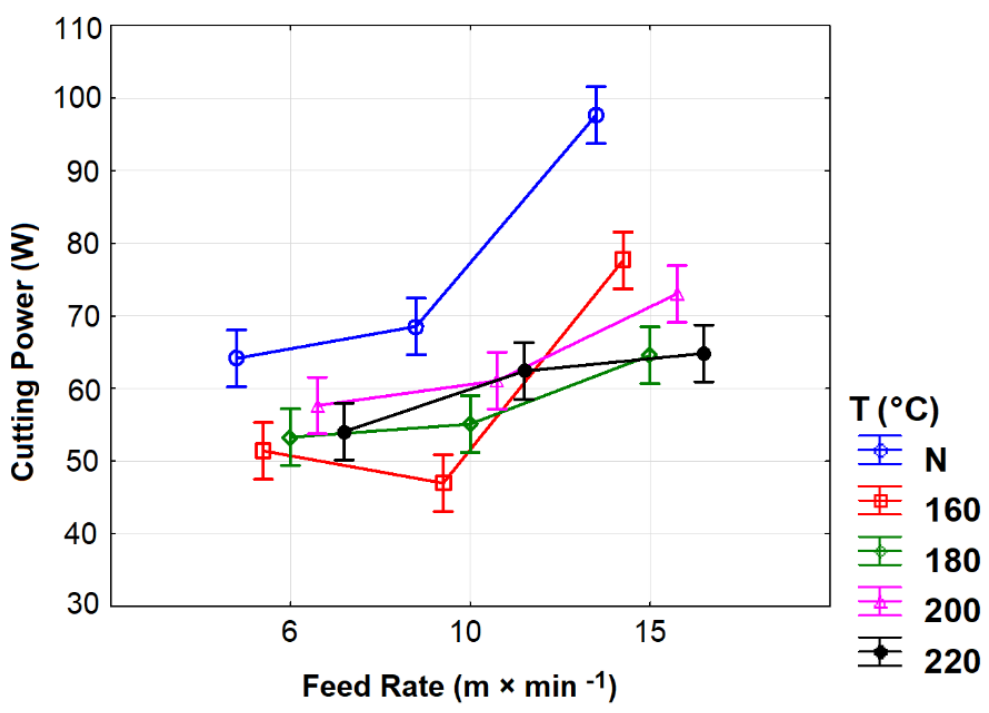

Fig. 13. Multifactor analysis of variance for the dependence of feed rate on cutting power 


\section{Influence of Cutting Speed on Cutting Power}

The multifactor analysis of variance of the dependence of cutting speed on cutting power is shown in Fig. 14. The cutting power increased proportionally to cutting speed. The highest cutting power was observed with the natural sample at a cutting speed of $60 \mathrm{~m}$ $\times \mathrm{s}^{-1}$. The lowest cutting power was achieved with a sample heat treated at $160{ }^{\circ} \mathrm{C}$ and a cutting speed of $20 \mathrm{~m} \times \mathrm{s}^{-1}$. All thermally treated samples had an approximately constant cutting power at the highest cutting speed of $60 \mathrm{~m} \times \mathrm{s}^{-1}$. In addition, at a cutting speed of $20 \mathrm{~m}^{\circ} \mathrm{s}^{-1}$, the samples thermally modified at $160{ }^{\circ} \mathrm{C}$ and $220^{\circ} \mathrm{C}$ had approximately equal cutting power values.

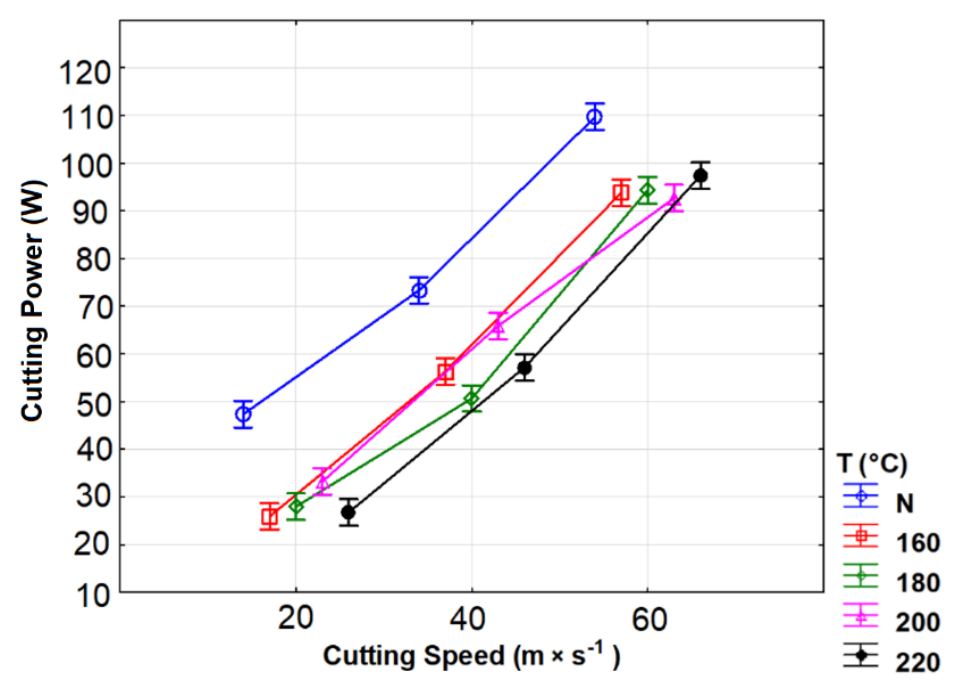

Fig. 14. Multifactor analysis of variance for the dependence of cutting speed on cutting power

\section{Influence of Rake Angle on Cutting Power}

For natural wood, the highest cutting power value was observed at the tool rake angle of $25^{\circ}$ (Fig. 15). In contrast, the lowest value of the cutting power was measured during milling of the sample heat treated at $160^{\circ} \mathrm{C}$ with a rake angle of $20^{\circ}$. An increase in cutting power values was visible when milling samples with a face angle of $25^{\circ}$, and a significant decrease in cutting power values was observed when milling samples with a face angle of $30^{\circ}$. 


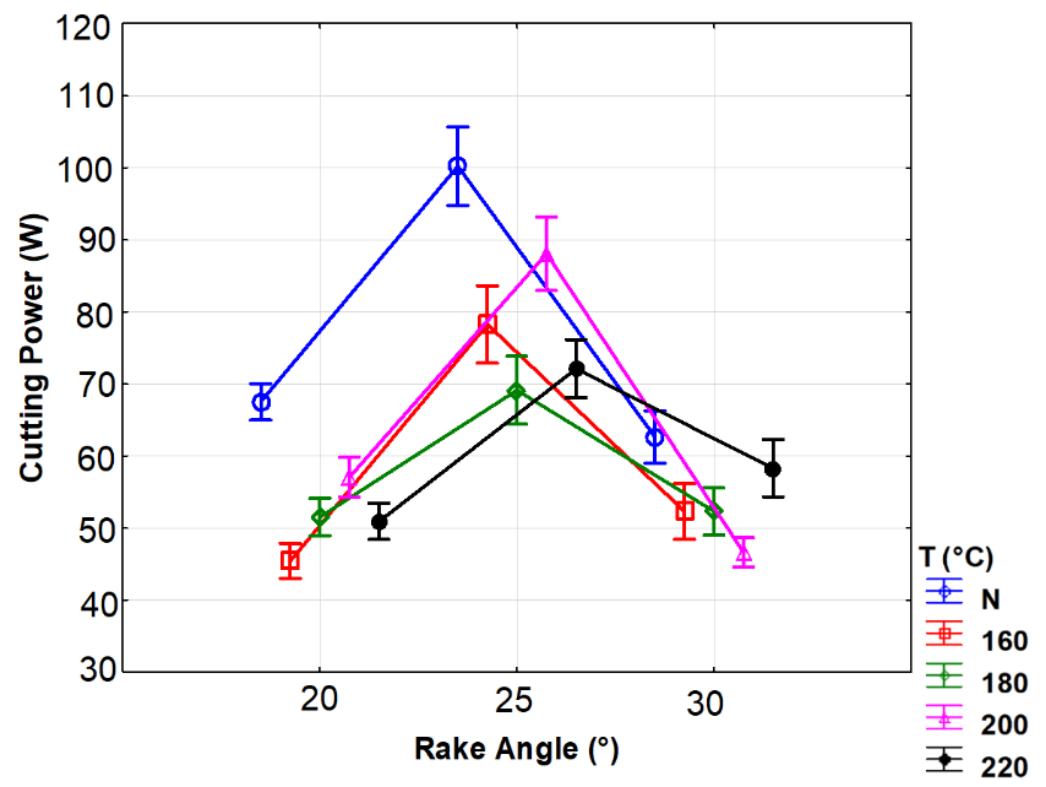

Fig. 15. Multifactor analysis of variance for the dependence of rake angle on cutting power

Table 6. The Order of the Effects of Various Factors on Cutting Power

\begin{tabular}{|c|c|c|}
\hline Effect on Cutting Power & F-test & $\begin{array}{c}\text { Significance Level } \\
(\mathrm{p})\end{array}$ \\
\hline Cutting Speed $\left({\left.\mathrm{m} \times \mathrm{s}^{-1}\right)}^{-1}\right.$ & 3453.77 & 0.000 \\
\hline Feed Rate $\left(\mathrm{m} \times \mathrm{min}^{-1}\right)$ & 356.46 & 0.000 \\
\hline Rake Angle $\left({ }^{\circ}\right)$ & 330.97 & 0.000 \\
\hline Temperature of Heat Treatment $\left({ }^{\circ} \mathrm{C}\right)$ & 117.5 & 0.000 \\
\hline
\end{tabular}

This study examined the dependence of $R_{\mathrm{a}}$ (mean arithmetic deviation of the roughness profile) and the consumed cutting power on the technical and technological parameters of planar milling of foreign natural and thermally treated meranti wood. The observed changes in values can be summarized as follows. The changes of roughness depending on thermal treatment was caused by chemical changes in the wood due to treatment temperature. As the feed rate increased, the surface roughness increased, which is in line with the theory of machining, which dictates that micro geometric roughness increases as the feed rate increases. Increasing the cutting speed reduces the micro geometric roughness what led to decreasing $R_{\mathrm{a}}$ value. Increasing the feed rate increased the amount of material removed per unit time, which caused an increase in cutting power. As the thermal treatment temperature increased, the wood became more brittle, and its density and cutting resistance decreased, which resulted in a decrease in cutting power. The increase in cutting power by increasing cutting speed was due to faster tool rotation and thus faster machining of the material.

The results of this study were similar to those reported by Vančo et al. (2019), who researched natural and thermally modified oak wood. Further, they found increased cutting speed led to improved surface quality, except for the sample heat treated at $160{ }^{\circ} \mathrm{C}$, which exhibited the opposite effect. Vančo et al. (2019) confirmed that increasing the feed rate 
reduces surface quality. The best results in terms of angular geometry were achieved at a rake angle of $30^{\circ}$, which is in line with the results of this study. In this study, when assessing the impact of heat treatment, the best surface quality was observed with heat treatment at $160{ }^{\circ} \mathrm{C}$.

According to Kaplan et al. (2018), who examined oak wood, thermal modification of wood does not affect the average roughness values after machining. The difference between the measured roughness values of treated and untreated wood was negligible. The lowest surface roughness values after machining were found at a rake angle of $25^{\circ}$. There was found out also that the best quality of surface after plane milling when $40 \mathrm{~m} \times \mathrm{s}^{-1}$ cutting speed was used. The best results in terms of the quality of the machined surface were measured at a feed rate of $4 \mathrm{~m} \times \mathrm{min}^{-1}$.

Korčok et al. (2017), who examined oak wood, reported the same effects of thermal treatment on surface quality. The best results were obtained with heat treatment of $160{ }^{\circ} \mathrm{C}$. The increase of surface roughness as heat treatment temperature increased was also observed. In terms of angular geometry, Korčok et al. (2017) also achieved the best surface quality at a rake angle of $30^{\circ}$.

According to Kvietková et al. (2015), who examined natural and heat-treated birch wood, the heat treatment of the material did not have a significant effect on the resulting quality, and the best surface roughness was achieved at a temperature of $210^{\circ} \mathrm{C}$, which conflicts with the results of this study. In terms of cutting speed, the trends of improving quality when the cutting speed was increased and the deterioration of surface quality when the feed rate was increased were also reported by the authors. Kvietková et al. (2015) measured the surface roughness via the contact method.

The energy consumption results of this study were similar to those reported by Koleda et al. (2020), who researched natural and thermally modified oak wood. They also reported that cutting power decreased as the heat treatment temperature increased. As cutting speed increases, the cutting power gradually increases. Cutting power increased as the feed rate increased for the sample heat treated at $220{ }^{\circ} \mathrm{C}$, the temperature at which the highest power was achieved at a feed rate of $10 \mathrm{~m} \times \mathrm{min}^{-1}$.

Kubš et al. (2016), who examined beech wood, or Sedlecký et al. (2019), who examined spruce and oak wood, also reported that increasing the cutting speed increases the cutting power. Further, Sedlecký et al. (2019) reported that increasing the feed rate increases the cutting power, but this effect is not as significant as at cutting speed.

According to Jamberová (2019), who examined natural and thermally treated oak wood, the heat treatment of the material also had a statistically significant effect on the cutting power (probability of similarity $<5 \%$ ). As the heat treatment temperature increases, cutting power decreases during milling. The heat treatment at $220{ }^{\circ} \mathrm{C}$ resulted in the lowest cutting power. The lowest cutting power value differed from that of this study, which was observed with heat treatment at $180{ }^{\circ} \mathrm{C}$. Further, Jamberová (2019) confirmed that increases in the feed rate also increase the cutting power. The results of the measurements confirm that cutting power also increases with increasing cutting speed. 


\section{CONCLUSIONS}

1. The quality of the treated surface depended on the observed factors, which were in the following order: 1) rake angle, 2) heat treatment, and 3) feed rate. The change in cutting speed did not show a statistically significant effect.

2. The most important determinant of surface quality was the angular geometry of the tool. It is recommended to use tools with a rake angle of $30^{\circ}$, as the best surface quality results were obtained with this angular geometry. In terms of heat treatment of the material, the best surface quality with this tool was achieved at $180^{\circ} \mathrm{C}$, and the worst quality was obtained at $220^{\circ} \mathrm{C}$.

3. Heat treatment of the material had a significant effect on the resulting surface quality. Based on the results, it is recommended to use a temperature of $160{ }^{\circ} \mathrm{C}$ for heat treatment of the material.

4. In terms of the influence of factors on the quality of surface treatment, the feed rate was in the third position. In terms of measured results, it is best to use the lowest feed rate to achieve good surface quality, which was $6 \mathrm{~m} \times \mathrm{min}^{-1}$.

5. Consumption of cutting power depended on the monitored factors, which were in the following order: 1) cutting speed, 2) feed rate, 3) angular geometry, and 4) heat treatment.

6. Based on the results, it is recommended to use a cutting speed of $20 \mathrm{~m}^{-1} \mathrm{~s}^{-1}$, at which the lowest value of cutting power was achieved for almost all examined samples. A slight deviation of the cutting power was shown for natural wood, which had a higher cutting power value. In contrast, the highest cutting power value was observed at a

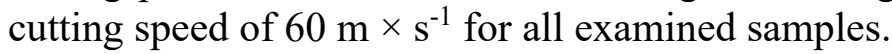

7. In terms of feed rate, the lowest cutting power was achieved at a feed speed of $10 \mathrm{~m} \times$ $\mathrm{min}^{-1}$ for wood heat treated at $160^{\circ} \mathrm{C}$, whereas the highest value of cutting power was achieved during milling of the native sample at a feed rate of $15 \mathrm{~m} \times \mathrm{min}^{-1}$.

8. The angular geometry of the tool was the third factor that affected the cutting power. The lowest value of the cutting power was achieved with a rake angle of $20^{\circ}$ at a temperature of $160{ }^{\circ} \mathrm{C}$, whereas the highest value of the cutting power was at a rake angle of $25^{\circ}$ with the untreated sample.

9. Heat treatment of wood was one of the least significant factors that affected the cutting power. The lowest cutting power value was achieved with a heat-treated sample at 180 ${ }^{\circ} \mathrm{C}$, whereas the highest cutting power value was observed with a natural sample.

10. Summarizing all factors affecting surface roughness and cutting power, it is recommended to use temperature of heat treatment of $160^{\circ} \mathrm{C}$, lower cutting speeds, feed rate in range of 6 to $10 \mathrm{~m} \times \mathrm{min}^{-1}$, and a rake angle of $30^{\circ}$. 


\section{ACKNOWLEDGMENTS}

This paper was supported by Grant. No. VEGA 1/0315/17 "Research of relevant properties of thermally modified wood at contact effects in the machining process with the prediction of obtaining an optimal surface," and Grant No. APVV 17/0456 "Thermal modification of wood with water vapor for purposeful and stable change of wood color."

\section{REFERENCES CITED}

Barcík, Š., Gašparík, M., Houska, A., Razumov, E. Y., and Sedlecký M. (2014). "Vliv technologických faktorů na kvalitu opracování povrchu při frézováni termicky modifikovaného borovicového dřeva [Influence of technological factors on surface finish quality during milling of thermally modified pine wood]," Trieskové a Beztrieskové Obrábanie Dreva 9(1), 11-22.

Boonstra, M. J., Van Acker, J., Tjeerdsma, B., and Kegel, E. V. (2007). "Strength properties of thermally modified softwoods and its relation to polymeric structural wood constituent," Annals Forest Sci. 64(7), 679-690. DOI: 10.1051/forest:2007048

Černecký, J., Brodnianská, Z., Blasiak, P., and Koniar, J. (2017). "The research of temperature fields in the proximity of a bundle of heated pipes arranged above each other," Journal of Heat Transfer 139(8), Article ID 082001. DOI: 10.1115/1.4036041

Esteves, B., and Pereira, M. H. (2009). "Wood modification by heat treatment: A review," BioResources 4(1), 370-404. DOI: 10.15376/biores.4.1.370-404

Hill, C. (2006). Wood Modification: Chemical, Thermal and Other Processes, John Wiley \& Sons, Ltd., Chichester, England.

ISO 4287 (1997). "Geometrical Product Specifications (GPS) - Surface texture: Profile method - Terms, definitions and surface texture parameters," International Organization for Standardization, Geneva, Switzerland.

Jamberová, Z. (2019). Analýza Faktorov Vplývajúcich Na Energetické Ukazovatele Pri Obrábani Termicky Modifikovaného Dubového Dreva [Analysis of Factors Affecting Energetic Parameters During Machining of Heat-treated Oak Wood], Dissertation Thesis, Technical University in Zvolen, Zvolen, Slovakia.

Kaplan, L., Kvietková, M. S., Sikora, A., and Sedlecký, M. (2018). "Evaluation of the effect of individual parameters of oak wood machining and their impact on the values of waviness measured by a laser profilometer," Wood Research 63(1), 127-140.

Kminiak, R., and Dzurenda, L. (2019). "Impact of sycamore maple thermal treatment on a granulometric composition of chips obtained due to processing on a CNC machining centre," Sustainability 11(3), Article ID 718. DOI: 10.3390/su11030718

Kminiak, R., Orłowski, K. A., Dzurenda, L., Chuchala, D., and Banski, A. (2020). "Effect of thermal treatment of birch wood by saturated water vapor on granulometric composition of chips from sawing and milling processes from the point of view of its processing to composites," Appl. Sci. 10(21), art. no. 7545. DOI: 10.3390/app10217545

Koleda, P., Barcík, Š., Korčok, M., Jamberová, Z., and Chayeuski, V. (2021). "Effect of technological parameters on energetic efficiency when planar milling heat-treated oak wood," BioResources 16(1), 515-528. DOI: 10.15376/biores.16.1.515-528

Koleda, P., Barcík, Š., and Nociarová, A. (2018) "Effect of technological parameters of machining on energy efficiency in face milling of heat - treated oak wood," 
BioResources 13(3), 6133-6146. DOI: 10.15376/biores.13.3.6133-6146

Korčok, M., Koleda, P., Barcík, Š., and Vančo, M. (2018a). "Effects of technical and technological parameters on the surface quality when milling thermally modified European oak wood," BioResources 13(4), 8569-8577. DOI:

10.15376/biores. 13.4.8569-8577

Korčok, M., Vančo, M., Barcík, Š., and Koleda, P. (2018b). "Influence of feed rate and cutting speed on final surface quality after plane plain milling of oak wood," Acta Facultatis Technicae Zvolen 23(2), 27-40.

Korčok, M., Vančo, M., Mazáň, A., Barcík, Š., Rudak, P., and Kminiak, R. (2017). "Influence of thermal modification of oak wood on final surface quality after plane milling," Acta Facultatis Technicae Zvolen 22(2), 103-112.

Kučerová, V., Lagaňa, R., Výbohová, E., and Hýrošová, T. (2016). "Effect of chemical changes during heat treatment on the color and mechanical properties of fir wood," BioResources 11(4), 9079-9094. DOI: 10.15376/biores.11.4.9079-9094

Kubš, J., Gaff, M., and Barcík, Š. (2016). "Factors affecting the consumption of energy during the milling of thermally modified and unmodified beech wood," BioResources 11(1), 736-747. DOI: 10.15375/biores.11.1.736-747

Kúdela, J., Lagaňa, R., Andor, T., and Csiha, C. (2020). "Variations in beech wood surface performance associated with prolonged heat treatment at $200{ }^{\circ} \mathrm{C}$," Acta Facultatis Xylologiae Zvolen 62(1), 5-17. DOI: 10.17423/afx.2020.62.1.01

Kvietková, M., Gašparík, M., and Gaff, M. (2015). "Effect of thermal treatment on surface quality of beech wood after plane milling," BioResources 10(3), 4226-4238. DOI: 10.15376/biores. 10.3.4226-4238

Lisičan, J. (1996). Teória a Technika Spracovania Dreva [Theory and Technique of Wood Processing], Matcentrum, Zvolen, Slovakia. (In Slovak)

Očkajová, A., Kučerka, M., Kminiak, R., Krišt'ák, L', Igaz, R., and Réh, R. (2020a). "Occupational exposure to dust produced when milling thermally modified wood," Int. J. Envir. Res. Pub. Health 17(5), article no. 1478. DOI: 10.3390/ijerph17051478

Očkajová, A., Kučerka, M., Kminiak, R., and Rogoziński, T. (2020b). "Granulometric composition of chips and dust produced from the process of working thermally modified wood," Acta Facultatis Xylologiae Zvolen 62(1), 103-111. DOI: 10.17423/afx.2020.62.1.09

Prokeš, S. (1982). Obráběni Dřeva a Nových Hmot Ze Dřeva [Machining of Wood and New Wood Materials], SNZI, Prague, Czech Republic.

Reinprecht, L., and Vidholdová, Z. (2008). Termodrevo - Príprava, Vlastnosti a Aplikácie, Technical University in Zvolen, Zvolen, Slovakia.

Sedlecky, M., Kvietková, M., Kubš, J., and Kubová, P. (2019). "The effect of milling parameters and thermal modification on power input during the milling of thermally modified spruce and oak wood," BioResources 14(1), 669-687. DOI: 10.15376/biores.14.1.669-687

Siklienka, M., and Kminiak, R. (2013). Delenie a Obrábanie Dreva. 1. Vyd. [Cutting and Machining of Wood. 1st Edition], Technical University in Zvolen, Zvolen, Slovakia.

Sikora, A., Kačík, F., Gaff, M., Vondrová, V., Bubeníková, T., and Kubovský, I. (2018). "Impact of thermal modification on color and chemical changes of spruce and oak wood," Journal of Wood Science 64, 406-416. DOI: 10.1007/s10086-018-1721-0 
STN 490108 (1993). "Wood. Determination of density," Slovak Office of Standards, Metrology and Testing, Bratislava, Slovakia.

Article submitted: April 7, 2021; Peer review completed: June 7, 2021; Revised version received and accepted: June 21, 2021; Published: October 8, 2021.

DOI: 10.15376/biores.16.4.7884-7900 